\begin{tabular}{|c|c|c|}
\hline $\begin{array}{l}\text { JURNAL } \\
\text { INOVASI } \\
\text { TEKNOLOGI } \\
\text { PENDIDIKAN }\end{array}$ & $\begin{array}{l}\text { Jurnal Inovasi Teknologi Pendidikan } \\
\text { Volume 4, No 2, October } 2017 \text { (116-129) } \\
\text { Online: http:/ /journal.unv.ac.id/index.php/iitp }\end{array}$ & $\begin{array}{l}\text { Ikatan Profesi Teknologi } \\
\text { Pendidikan Indonesia }\end{array}$ \\
\hline
\end{tabular}

\title{
PENGEMBANGAN E-LEARNING ADAPTIF PADA MATA PELAJARAN PENDIDIKAN AGAMA ISLAM UNTUK KELAS X SMA
}

\author{
Ziaurrahman, Herman Dwi Surjono \\ Program Studi Teknologi Pendidikan PPS UNY, Universitas Negeri Yogyakarta \\ zia.edutech@gmail.com, hermansurjono@uny.ac.id
}

\begin{abstract}
Abstrak
Penelitian ini bertujuan untuk: (1) menghasilkan produk e-learning adaptif berbasis web untuk siswa kelas X SMA pada mata pelajaran Pendidikan Agama Islam, (2) mengetahui kelayakan produk e-learning adaptif, dan (3) mengetahui kebermanfaatan produk melalui peningkatan hasil belajar. Jenis penelitian ini merupakan penilitian dan pengembangan (R\&D) diadaptasi dari model Alessi dan Trollip. Prosedur pengembangan meliputi tahap perencanaan, desain, dan pengembangan. Pada uji alpha dilakukan penilaian oleh 2 ahli materi dan 2 ahli media untuk mengetahui kelayakan produk. Tahap berikutnya dilakukan uji beta 1 terhadap 5 siswa kelas X-I dan uji beta 2 sebanyak 25 siswa kelas X-G. Selanjutnya tes sumatif terhadap 25 siswa. Hasil penelitian menunjukkan bawah (1) Produk e-learning adaptif berbasis web dengan fasilitas meliputi: tes gaya belajar, paket bahan ajar (mode umum dan khusus visual auditori dan kinestetik), forum perkenalan, diskusi, dan chatting; (2) produk telah layak digunakan berdasarkan validasi 2 ahli media; (3) terjadi peningkatan pencapaian hasil belajar kognitif siswa setelah menggunakan e-learning adaptif.

Kata kunci: pengembangan, e-learning adaptif, mata pelajaran Pendidikan Agama Islam.
\end{abstract}

\section{DEVELOPING AN ADAPTIVE E-LEARNING MEDIA IN THE ISLAM EDUCATION SUBJECT MATTER OF GRADE X FOR SMA}

Ziaurrahman, Herman Dwi Surjono

Program Studi Teknologi Pendidikan PPS UNY, Universitas Negeri Yogyakarta zia.edutech@gmail.com, hermansurjono@uny.ac.id

\section{Abstract}

This research study aims to: (1) Develop a web-based adaptive e-learning media for the Islam Education subject matter of grade X of SMA Negeri 11 Yogyakarta, (2) identify the appropriateness of the developed adaptive e-learning product, and (3) identify the usefulness of the developed media through the improvement of students' learning outcome. This study was a research and development (RED) study adapting Alessi and Trollip's model. The procedures of the study were planning, design, and development. In the alpha test, two materials experts and two media experts examined the product to determine its appropriateness. The next stage tested the beta 1 to 5 class X-I and beta 2 test as many as 25 students of class X - G. Further more summative test to 25 students. The results of the study are as follows: (1) the web-based adaptive e-learning media consisted of tes learning style, a package of learning material (the general and specific modes of visual, auditory, and kinaesthetic), an introduction forum, discussion, and chatting, (2) The developed media is appropriate to use based on the results of the validation by the media experts, (3) There is an improvement of the cognitive learning achievement of the students after the use of the adaptive e-learning media.

Keywords: development, adaptive e-learning, islam education subject matter 


\section{Pendahuluan}

Pendidikan Agama Islam di abad 21 tidak berada di ruang yang vakum. Peserta didik di abad 21 sudah sangat akrab dengan teknologi. Guru sebagai tenaga pendidik bertugas menjadikan peserta didik yang taat mengamalkan nilai-nilai agama Islam, bukan mengajak peserta didik untuk melawan arus zaman. Perkembangan abad 21 terdapatnya berbagai macam tantangan (Kementrian Agama Rebulik Indonesia, 2015). Salah satu tantangan adalah timbulnya persaingan terhadap arus dunia global. Dunia global dalam dimensi abad 21, dipahami sebagai arus transformasi pengetahuan yang berbasis daya saing yang ditandai dengan sistem keterbukaan informasi.

Melalui sistem keterbukaan informasi, seseorang berkemampuan meraih kesukses dan menjadi yang terdepan apabila mampu menguasai serta mengelola informasi. Oleh sebab itu, diperlukan suatu persiapan yang lebih serius dari lembaga pendidikan. Lembaga pendidian dipandang sebagai salah satu lembaga yang mampu melahirkan generasi-generasi emas dan menjawab tantangan dunia global.

Lembaga Pendidikan sebagai penyelenggaran dan wadah pencetak generasi penerus bangsa, memiliki peran yang insidental untuk merestorasi dan mensinkronisasi pembelajarandalam tatanan pelaksanaan sistem pendidikan di Indonesia. Karena pembelajaran abad 21 siswa dihadapkan oleh berbagai perkembangan teknologi dan informasi (TIK) begitu cepat sehingga membawa perubahan dan tuntutan baru. Berlandaskan pemikiran tersebut, siswa harus dibekali dengan berbagai skill dan keterampilan, sebagaimana yang dilansir oleh Partnership for 21st Century Learningbahwa siswa harus menguasai skill seperti informasi, media dan keterampilan teknologi, komunikasi dan keterampilan kolaborasi, dan berpikir kritis, keterampilan pemecahan masalah (Pheeraphan, 2013, p. 366; Greenstein, 2012, p. 6).

Guna memenuhi dan melakukan suatu upaya ikhtiar agar pendidikan In- donesia mampu beradaptasi sesuai perkembangan zaman, maka dalam hal ini lembaga pendidikan melalui badan Badan Penelitian dan Pengembangan Kementerian Pendidikan dan Kebudayaan (2013) telah merumuskan suatu konsep pembelajaran abad 21. Rumusan pembelajaran yang dimaksud bahwa peserta didik diharapkan memiliki kemampuan dalam mengumpulkan informasi dari berbagai sumber, merumuskan permasalahan, berpikir analitis, kerja sama, dan dapat berkolaborasi dalam menyelesaikan permasalahan. Berdasarkan penjelasan tuntutan pembelajaran abad 21, suatu pertanda lahirnya pembelajaran modern. Penguasaan teknologi dan informasi (TIK) menjadi hal penting bagi peserta didik agar pengetahuan tertentu bisa dicapai dengan cepat, mudah, dan tentunya tidak dibatasi oleh ruang dan waktu tertentu. Maka dalam hal ini pula peserta didik perlu dibudayakan untuk belajar online. Adapun alternatif lain adalah guru, siswa, dan seluruh unsur pendidikan diharuskan untuk mampu menguasai dan mengintegrasikan TIK kedalam pembelajaran. Langkah dan upaya ini dilakukan bertujuan sebagai salah satu langkah alternatif supaya dapat tercapainya tujuan pendidikan sesuai arus perkembangan zaman.

Tujuan pendidikan dalam skala nasional di abad 21 adalah mewujudkan cita-cita bangsa, yaitu masyarakat Indonesia yang sejahtera dan bahagia, dengan kedudukan yang terhormat dan setara dengan bangsa lain dalam dunia global, melalui pembentukan masyarakat yang terdiri dari sumber daya manusia yang berkualitas, yaitu pribadi yang mandiri, berkemauan dan berkemampuan untuk mewujudkan cita-cita bangsanya (Badan Standar Nasional Pendidikan, 2010, p. 39). Capaian rumusan tujuan pendidikan Indonesia dapat diwujudkan berdasarkan tujuan pendidikan sekolah. Adapun tujuan pendidikan sekolah dapat dicapai melalui mata pelajaran, salah satunya mata pelajaran Pendidikan Agama Islam (PAI). Rumusan tujuan PAI di SMA sebagaimana 
yang tertera dalam standar isi untuk Satuan Pendidikan Dasar dan Menengah Atas, sebagai berikut.

Menumbuhkembangkan akidah melalui pemberian, pemupukan, dan pengembangan pengetahuan, penghayatan, pengamalan, pembiasaan, serta pengalaman peserta didik tentang Agama Islam sehingga menjadi manusia muslim yang terus berkembang keimanan dan ketakwaannya kepada Allah swt., dan mewujudkan manusia Indonesia yang taat beragama dan berakhlak mulia yaitu manusia yang berpengetahuan, rajin beribadah, cerdas, produktif, jujur, adil, etis, berdisiplin, bertoleransi (tasamuh), menjaga keharmonisan secara personal dan sosial serta mengembangkan budaya Agama dalam komunitas sekolah (Badan Standar Nasional Pendidikan , 2006, p.50).

Arifin dalam buku filsafatnya mengatakan bahwa tujuan Pendidikan Agama Islam (PAI) adalah untuk menumbuhkan keseimbangan diri manusia secara menyeluruh melalui latihan-latihan kejiwaan, akal pikiran, kecerdasan, perasaan dan pancaindra sehingga diperoleh kesempurnaan hidup yang melibatkan seluruh aspek kehidupan manusia (Engku \& Zubaidah, 2014, pp. 4-5). Hakikat tujuan Pendidikan Agama Islam adalah menjadikan manusia yang seutuhnya (paripurna). Manusia paripurna adalah manusia yang sudah mampu menjalankan perintah dan meninggalkan larangan Allah Swt. sehingga pada akhirnya disebut sebagai insan kamil (manusia sempurna).

Tujuan dari pembelajaran PAI berdasarkan fakta yang ada di lapangan bahwa terdapatnya sekolah yang belum mencapai secara maksimal tujuan PAI yang diukur melalui kriteria ketuntasan minimal (KKM). Salah satunya yang terjadi di SMA Negeri 11 Yogyakarta. Hasil survei di SMA Negeri 11 Yogyakartapada tanggal 24 November 2015 tentang hasil belajar siswa, membuktikan bahwa sebagian siswa memiliki nilai dibawah kriteria ketuntasan minimal (KKM)sebanyak 65\% sedangkan yang mencapainya adalah sebanyak $45 \%$.
Kemudian dilakukan pula survei lebih lanjut berkaitan dengan strategi guru mengajar, gaya belajar, dan media.

Selama ini guru PAI di SMA Negeri 11 Yogyakarta pada saat mengajar masih menggunakan metode dan cara penyampaian materi dengan cara yang sama kepada setiap siswa. Hal ini, diungkapkan oleh siswa melalui hasil analisis angket dengan jumlah persentasenya sebanyak $91 \%$. Upaya guru dalam mengajar teridentifikasi menggunakan strategi yang harus diperbaiki karena sudah mengabaikan sisi karakteristik siswa (gaya belajar). Mengabaikan gaya belajar siswa akan berdampak pada hasil belajar, sebagaimana hasil penelitian yang dilakukan oleh Magdalena (2014, p. 1667) tentang hubungan gaya belajar dengan hasil belajar, bahwa terdapatnya korelasi yang erat antara gaya belajar dengan hasil belajar.

Gaya belajar merupakan bagian dari pada pendekatan dalam upaya guru menyampaikan isi materi. Urgensi gaya belajar dalam pembelajaran karena dapat mengantarkan siswa dalam memahami materi secara efektif, efisien, cepat, dan muda dalam mengelola informasi tertentu. Dalam beberapa literatur gaya belajar sebagaimana yang dijelaskan oleh Ducket \& Tatarkowski (2005, p. 11), "A learning style is the way in which an individual learner tries to learn. It concerns the ways in which learners approach and experience learning, and use information." Gaya belajar adalah suatu pendekatan dan cara untuk mendapat informasi yang lebih tepat. Berbeda halnya yang dikatakan oleh Vaughan (Surjono, 2011, p. 117) gaya belajar adalah kebiasaan seseorang merasa paling efisien dan efektif dalam menerima, memproses, menyimpan dan mengeluarkan sesuatu yang dipelajari. Jadi, gaya belajar dalam konteks pembelajaran, dapat dipahami sebagai suatu pendekatan dalam rangka mengefektifkan pembelajaran dalam rangka mencapai hasil belajar yang lebih baik.

Sementara hasil identifikasi gaya belajar siswa SMA Negeri 11 Yogyakarta pada kelas $\mathrm{X}$, sebanyak 54 siswa yang 
dijadikan sampel dari jumlah total keseluruhan 288 siswa terdapat perbedaan gaya belajar. Identifikasi gaya belajar yang dilakukan diantaranya visual, audio, dan kinestetik. Hasil identifikasi dari setiap jenis gaya belajar adalah visual sebanyak 33\%, audio $32 \%$, dan kinestetik 35\%. Adapun terkait dengan media pembelajaran yang digunakan oleh guru masih sebatas tayangan slide power point, peng-gunaannya pun tergolong kedalam kategori jarang. Hal ini disampaikan oleh guru PAI melalui hasil wawancara pada saat pelaksanaan pra survei. Lebih lanjut guru PAI mengatakan, alokasi jam mengajar yang diberikan masih sangat terbatas, yakni hanya 90 menit sehingga sulit untuk mengajak siswa untuk mengeksplorasi lebih jauh terkait dengan materi yang diajarkan.

Beberapa permasalahan dan kendala yang di alami oleh guru mata pelajaran PAI di SMA Negeri 11 Yogyakarta, timbul kesulitan-kesulitan yang dialami siswa dalam memahami dan mempelajari lebih mendalam materi yang diajarkan. Dalam menghafal dalil (Alquran dan hadis), siswa kelas $\mathrm{X}$ mengalami kesulitan pula. Data diperoleh dari hasil analisis angket, dimana sebanyak $80 \%$ mengatakan sulit dan $20 \%$ lagi mengatakan tidak, sehingga mempengaruhi siswa dalam memahami isi kandungan dalil, walaupun jumlah persentasenya tidak begitu signifikan yakni 59\% siswa merasa kesulitan dan hanya $41 \%$ siswa yang mampu memahaminya. Alquran merupakan sumber pokok Islam pertama sedangkan yang kedua adalah hadis. Kedua sumber hukum Islam tersebut merupakan pedoman bagi ummat Islam sehingga menghafal dan memahami isi kandungan sangatlah penting bagi siswa umum ummat Islam. Melalui tahapan mengahafal Alquran dan hadis akan membawa seseorang kepada jalan kebaikan sebagaimana yang diperintahkan oleh Allah Swt. karena sudah memahami hukum-hukum yang telah digariskan terkait benar dan salah.

Berdasarkan permasalahan, kesulitan yang dialami oleh siswa kelas X SMA Negeri 11 Yogyakarta, dan tuntutan per- kembangan abad 21 salah satu bentuk solusi yaitu dengan melakukan pendekatan pembelajaran berbasis TIK. Pembelajaran melalui e-learning merupakan salah satu pendekatan dan pola pemanfaatan TIK. Melalui implementasi pembelajaran dengan menjadikan e-learning sebagai media dan sumber belajar dimungkinkan akan melahirkan pengalaman belajar yang fleksibel (Horton \& Horton, 2003 ,p. 13; Naidu, 2006, p. 4; Henderson, 2003 ,p. 6). E-learning memiliki kemampuan fleksibel terhadap distribusi materi dan dapat digunakan kapan dan dimana saja tanpa dibatasi oleh letak geografistertentu (Pannen, 2005, pp. 1-2).

Adapun e-learning yang cocok dan sesuai dengan permaasalahan yang ada di SMA Negeri 11 Yogyakarta, bahwa model e-leanring adaptif dipandang tepat, karena e-learning adaptif adalah suatu model $e$ learning yang dirancang atas dasar kebutuhan pembelajar individu. Brusilovsky (2001, p. 87) mengatakan adaptive hypermedia termasuk kajian pemodelan penguna dan masih tergolong baru. Sistem adaptive hypermedia membangun model tujuan, preferensi, dan pengetahuan tiap individu. Pendapat Brusilovskylebih lanjut dijelaskan oleh Surjono $(2008$, p. 2) bahwa e-learning adaptif adalah suatu model yang dirancang atas asumsi pembelajaran individu. E-learning adaptif juga mampu menampilkan halaman web sesuai karakteristik indvidu, berorientasi pada kelompok pengguna yang lebih luas, dan memberikan navigasi untuk membatasi keluasan pengguna dalam mencari informasi.

Pengembangan e-learning adaptif dimungkinkan dapat (1) mengatasi keterbatasan jumlah jam mengajar, (2) siswa dapat belajar dengan berdasarkan pendekatan individual, (3) meningkatnya penguasaan pemahaman siswa terhadap suatu materi pembelajaran, (4) sehingga tujuan pembelajaran PAI bisa tercapai sebagaiman ketentuan yang telah ditetapkan. Adapun adaptif yang dimaksud dalam penelitian pengembangan e-learning ini adalah adaptasi dengan gaya belajar visual, audio, dan kinestetik (VAK). Bahan ajar (isi materi) di- 
kembangkan dengan mempertimbangkan gaya belar siswa sehingga materi dan informasi yang disampaikan dapat diterima dengan mudah. Materi yang cocok untuk penerapan tipe VAK misalnya memahami hukum Islam tetang zakat, haji, dan wakaf. Dalam materi ini siswa diminta untuk mampu menjelaskan tentang pengelolaan wakaf menurut undang-undang berdasarkan anjuran berdasarkan dalil-dalil yang ada, menyebutkan contoh serta bagaimana cara mempraktikkan. Materi ini dapat divisualisasikan, dinarasikan dalam bentuk audio dan, didesain program media dalam bentuk puzzle.

Pelaksanaan pengembangan e-learning adaptif dilandasi oleh beberapa teori belajar. Pengembangan e-learning dengan melandasi pada teori belajar supaya pesan yang didesaian dapat tersampai kepada siswa. Teori belajar dipahami sebagai suatu kumpulan konsep yang diimplementasikan dalam pembelajaran sebagai langkah penghubung pengetahuan kepada peserta didik. Oleh sebab itu, menurt Ally (2004, pp. 7-8) mengatakan ada tiga teori umum yang melandasi pengembangan e-learning yaitu teori behavioristik, kognitif, dan konstruktifistik.

Adapun implementasinya dalam pengembangan e-learning adaptif diadopasi dari pengembangan e-learning sebagaimana yang dikatakan oleh Surjono (2008, pp. 56). Teori pertama adalah behavioristik (1) tujuan pembelajaran perlu ditampilkan, (2) pencapaian belajar perlu dinilai, dan (3) umpan balik perlu diberikan. Teori kedua adalah kognitif, (1) informasi yang penting perlu diletakkan di tengah layar dan perlu ditonjolkan untuk menarik perhatian, (2) informasi perlu ditampilkan sedikit demi sedikit untuk menghindari terjadinya beban lebih pada memori, dan (3) materi pembelajaran perlu disajikan sesuai dengan gaya belajar pesertadidik. Ketiga adalah teori konstruktivistik (1) program e-learning perlu bersifat interaktif, (2) contoh dan latihan perlu bermakna, (3) peserta didik dapat mengontrol jalannya pembelajaran.

Berdasarkan hasil observasi terkait sistem pembelajaran di sekolah, bahwa pe- laksanaan pembelajaran menggunakan sistem tatapmuka. Artinya pembelajaran dilaksanakan secara klasikal, oleh itu karena e-learning adaptif yang dikembagkan tidak dapat di gunakan secara full online maka alternatif pelaksanaan model blended learning. Blended learning sebagaimana yang dikatakan oleh Bersin (2004, p.12)

Blended learning is the combination of different training"media"(technologies, activities, and types of events) to create an optimum training program for a specific audience. The term "blended" means that traditional instructor-led training is being supplemented with other electronic formats. In the context of this book, blended learning programs use many different forms of e-learning, perhaps complemented with instructor-led training and other live formats. Pendapat lain sebagaimana yang diungkapkan oleh Rusman \& Riayana (2012, p.245) blended e-learning merupakan kombinasi atau pengambungan pendekatan aspek blended e-learning yang berupa web-based instruction, video streaming, audio, komunikasi synchronous dan asynchronous dalam jalur blended e-learning system LSM dengan pembelajaran tradisional "tatap muka" termasuk juga metode mengajar, teori belajar, dan dimensi pedagogik.

Jadi Blended learning adalah pembelajaran yang dilaksanakan oleh guru dengan melakukan kombinasi antara tatap muka dengan online. Istilah blended adalah suatu kelas yang difasilitasi oleh guru, dilengkapi dengan berbagai atribut elektronik dan menggunakan berbagai bentuk $e$ learning.Tujuannya agar peserta didik dapat mengoptimalkan diri dalam mengikuti proses pembelajaran dan untuk mengoptimalkan proses dan layanan pembelajaran.

Pengembangan e-learning adaptif pada saat diimplementasi agar mendapatkan hasil sesuai yang diharapkan maka dibutuhkan beberapa indikator penilaian (evaluasi). Alessi \& Trollip (2001, p. 549) menjelasakan beberapa hal umum yang harus diperhatikan pada saat evaluasi hypermedia atau e-learning, yaitu Subject matter (lingkup materi), Auxiliary information (informasi pendukung), Affective considerations 
(petunjuk sikap), Interface (komunikasi pengguna dengan program), navigasi, $\mathrm{Pe}$ dagogy (aktivitas belajar), Invisible features (fitur yang sulit dilihat), dan Robustness (kehandalan) dan, Supplementary (materi pengayaan). Untuk mendapatkan hasil sesuai kebutuhan dilakukan kolaborasi dan adaptasi indikator penilaian. Evaluasi lain sebagaiman yang diungkapkan oleh Surjono (2013, pp.75-76) aspeknya meliputi materi, tampilan antarmuka, dan pedagogik. Adapun aspek indikator evaluasi yang ditetapkan dalam penelitian ini adalah pertama untuk ahli materi, pembelajaran, materi, leanring style, dan media. Kedua adalah ahli media, interface, navigasi, hiden fiture, accessbility, dan pengguna. Ketiga adalah untuk pengguna, materi, learning style, interface, danpedagogik. Pengguna sebelum melakukan penilaian akan diajarkan dengan menggunakan e-learning adaptif dan proses penilaian dibimbing langsung oleh pengembang. Sementara evaluasi sumatif dilaksanakan pada saat produk sudah selesai dan uji coba beta 2. Tujuan untuk mendapatkan tingkat efektifitas dari suatu produk e-learning. Menurut Davidson \& Rasmussen (Surjono, 2013, p.82) tujuan utama dari evaluasi sumatif yang pertama adalah untuk menentukan kebermagnaan program dalam hal evektfitas, efisien, dan daya tarik. Kedua untuk mengetahui nilai ada atau tidaknya peningkatan hasil setelah menggunakan e-learning dan yang ketiga adalah upaya pengambilan keputusan antara menggunakan apa adanya atau modifikasi bahakan dihentikan.

Selain beberapa alasan pengembangan e-learning adapatif yang telah dijelaskan sangat penting informasi hasil penelitian yang relevan. Penelitian terkait pembelajaran online berbasis gaya belajar salah satunya penelitian yang telah dilakukan oleh Permadi (2015, p. 1) yaitu tentang web pembelajaran berdasarkan gaya belajar siswa. Hasil pengembangan produk efektif dan layak digunakan dengan ketuntasan belajar siswa mencapai 97\% (30 dari 31 siswa). Hasil penilaiannya didapat dari responssiswa setelah menggunakan media pembelajaran, menunjukkan kategori baik dengan rerata skor 4,15. Beberapa faktor pendukung pelaksanaan pengembangan $e$ learning adaptifantara lain; adanya permasalahan pada mata pelajaran PAI, terdapat perbedaan gaya belajar siswa, materi cocok di implementasikan pada tipe gaya belajar visual, audio, dan kinestetik serta turut didukung oleh pihak. Adapun faktor lain sebagaimana yang dijelaskan dalam Tabel nomor 1 .

Tabel 1. Hasil Analisis Angket Siswa

\begin{tabular}{clcc}
\hline No & \multicolumn{1}{c}{ Komponen } & Ya & Tdk \\
\hline 1 & $\begin{array}{l}\text { Saya memiliki } \\
\text { laptop/komputer }\end{array}$ & $100 \%$ & $0 \%$ \\
2 & $\begin{array}{l}\text { Saya terbiasa mengakses } \\
\text { internet }\end{array}$ & $67 \%$ & $33 \%$ \\
3 & $\begin{array}{l}\text { Saya menyukai } \\
\text { pembelajaran online }\end{array}$ & $74 \%$ & $26 \%$ \\
\hline
\end{tabular}

Berdasarkan tabel nomor 1 tentang hasil analisis angket siswa, bahwa semua siswa kelas $X$ telah memiliki laptop. Sebanyak $67 \%$ data diperoleh bahwa siswa terbiasa mengakses internet, dan $74 \%$ menyukai pembelajaran online. Selain itu, guru juga telah memiliki laptop sebagai perangkat untuk mengakses e-learning adaptif. Lembaga sekolah dari segi sarana dan prasarana telah tersedia, dan dapat digunakan. Hal ini dibuktikan dengan adanya laboratorium komputer, selain itu pihak sekolah juga telah menyediakan jaringan internet (wifi).

Harapanya melalui pengembangan e-leanring adaptif dapat menjadi langkah awal dari pada meningkat hasil belajar, mutu, dan kualitas lulusan serta memotivasi pihak yang terkait bahwa diperlukan daya kreativitas dan semangat untuk terus berbenah dalam rangka memfasilitasi pembelajaran yang lebih baik kepada siswa. Maka oleh karena itu, berdasarkan permasalahan, kesulitan, solusi dan faktor yang mendukung pengembangan e-leanring adaptif di SMA Negeri 11 perlu dikembangkan.

Berdasarkan urain yang telah disampaikan, penelitian ini bertujuan untuk mengembangakan e-learning adaptif yang 
diimplementasikan sebagai suatu media atau sumber belajar berbasis web yang terfokus pada perbedaan gaya belajar siswa. Pengembangan media dan sumber belajar ini akan diterapkan untuk siswa kelas $X$ SMA Negeri 11 Yogyakarta. Adapun mata pelajaran yang diambil adalah pendidikan Agama Islam, konsen pada materi wakaf.

\section{Metode Penelitian}

Jenis penelitian ini merupakan penelitian pengembangan. Model pengembangan diadopsi dari model Alessi \& Trollip (2001, p. 410) dengan tahapan pengembangan secara umum meliputi perencanaan (planning), desaian(design), dan pengembangan (development). Setiap tahapan meliputi standar (standars), evaluasi berkelanjutan (ongoing evaluation), dan manajemen proyek (project management) sebagai pelengkap dan bahan pertimbangan dalam mengembangkan produk e-learning adaptif.

Penelitian ini menggunakan pendekatan kuantitatif. Data-data kuatitatif dianalisis menggunakan statistik deksripsi sehingga data dijabarkan dalam bentuk kualitatif. Tujuannya adalah untuk mengetahui kela-yakan dan efektifitas dari pengembangan e-learnning adaptif.

Penelitian ini dilaksanakan dalam kurun waktu selama 6 bulan, terhitung dari bulan November 2015-April 2016. Tempat penelitian di SMA Negeri 11 Yogyakarta.

Responden atau subjek dalam penelitian ini adalah peserta didik kelas X-I untuk uji coba beta 1 dan uji cobe beta 2 kelas X-G SMA Negeri 11 Yogyakarta tahun ajaran 2015/2016. Subjek atau responden selanjutny dalam penelitian terdiri dari 2 ahli media dan materi. Validasi ahli media bertujuan untuk menilaian dan mengevaluasi produk sebelum diterapkan baik beta 1 maupun beta 2 . Sedangkan ahli materi untuk menilaikelayakan materi sebelum diuji cobakan.

Prosedur pelaksanaan pengembangan menyesuaikan berdasarkan kebutuhan di lapangan dan kajian ruang lingkup da- lam penelitian. 3 fase awal dari pengembangan e-learning adaptif adalah (a) standar, yaitu mendefinsikan kualitas dari portal e-learning adaptif, dalam hal ini terlibat pengembanga, pembimbing, dan guru PAI SMA Negeri 11 Yogyakarta, (b) ongoing evaluation, yaitu melakukan evaluasi simultan terhadap produk dari tahap awal hingga akhir pengembangan dengan mengacu pada standar yang telah ditetapkan sebelumnya. (c) projects management, mengatur dan mempertimbangkan waktu penelitian, dana sumber daya yangtersedia, termasuk komunikasi antara pihakterkait.

Prosedur pengembangan selanjutnya antara lain; (1) perencanaan (planning), tahapan perencanaan merupakan tahap persyaratan awal untuk melihat peluang dan kesiapan untuk mendesaian. Tahapantahapan antara lain; mendefenisikan bidang atau ruang lingkup (define the scope), mengidentifikasi karakteristik siswa (identify learner characteristic, memproduksi dokumen perencanaan, identifikasi sumbersumber dan daya dukung (determine and collect resources), dan melakukan brainstorming dengan guru PAI SMA Negeri 11 Yogyakarta berkaitan dengan materi yang akan diaplikasikan, teman sejawat, dan pembimbing; (2) Desain (Design), tahapan ini antara lain, melakukan analisis konsep dan tugas (conduct task and concept analysis, membuat flowcharts, menentukan software, evaluasi dan revisi; (3) Pengembangan (Development), Prosedur pengembangan terdiri dari 10 langkah.

Dalam penelitian pengembangan $E$ learning Adaptif diambil 6 langkah. Hal ini mengacu pada hasil analisis kebutuhan di lapangan dan ruang lingkup dalam pelaksanaan mengabungkan bagian-bagian (Assemble The Pieces), membangun portal, mempersiapkan materi pendukung (Prepare Support Materials), melakukan evaluasi formatif, dan evaluasi sumatif bertujuan untuk mengetahui kebermanfaatan produk dari peningkatan pembelajaran melalui nilai "gain" terhadap KKM.

Jenis data dalam penelitian pengembangan ini terdiri dari dua yaitu ku- 
antitatif dan kualitatif. Data kuantitatif dieperoleh dari hasil validasi oleh ahli materi, media, dan peserta didik. Sedangkan data kualitatif juga diperoleh dari ahli media, materi, dan peserta didik berdasarkan saran, kritikan dan masukan pada saat validasi dan uji coba produk. Selaian itu, data kualitatif diperoleh pula dari hasil wawancara dengan guru, pengelola laboratorium, dan kepala sekolah pada saat melakukan prasurvei. Perolehan data baik kuantitatif atau kualitatif dideskripsikan sebagai bahan pertimbangan untuk merevisi produk yang dikembangkan. Kedua data tersebut juga digunakan untuk mengukur kualitas kebermanfaatan produk supaya dapat diterapkan dalam proses pembelajaran.

Instrumen yang digunakan dalam penelitian dan pengembangan ini terdiri dari angket, wawancara, soal tes uji kompetensi dan dokumentasi. Angket digunakan pada saat pra survei, ahli materi, ahli media, dan peserta didik pengguna produk. Wawancara dilakukan pada saar prasurvei, soal tes uji kompetensi digunakan pada saat pretest dan posttest. Dan dokumentasi digunakan dari prasurvei sampai pelaksanaan uji sumatif. Berkaitan dengan instrumen, tahapan penggunaan dilakukan setelah di validasi oleh ahli media, materi, instrumen gaya belajar, dan angket untuk peserta didik. Sedangkan soal uji kompetensi divalidasi oleh ahli materi bersamaan denan proses validasi materi.

Adapun teknik pengumpulan data dalam penelitian ini menggunakan kuisioner (angket), observasi, wawancara dan soal uji kompetensi. Sedangkan instumen yang digunakan adalah angket, lembar observasi,pedoman wawancara dan soal pretest dan posttes.

Teknik analisis data yang digunakan adalah analisis deskriptif kuantitatif dengan melakukan analisis terhadap data kuantitatif dari hasil pengujian. Pengambilan data tentang kelayakan produk menggunakan skla liker 4 , hal ini untuk menghindari jawaban 3, netral maupun cukup yang cenderung dipilih oleh pengguna.
Adapun langkah-langkahnya adalah mengumpulkan data mentah, pemberian skor, mengkonversi data yang diperoleh ke dalam skala 4. Acuan skala 4 menggunakan kriteria yang dikembakan oleh Mardapi (2008, p. 123).

Tabel 2. Kriteria Acuan Penskoran

\begin{tabular}{lll}
\hline Skor siswa & Skor & Interpretasi \\
\hline$X \geq X+1 . S B x$ & 4 & sangat layak \\
$X+1 . S B x>X \geq X$ & 3 & layak \\
$X>X \geq X-1 . S B x$ & 2 & tidak layak \\
$X<X-1 . S B x$ & 1 & sangat tidak layak \\
\hline
\end{tabular}

Keterangan tabel:

$X$ : Rerata skor keseluruhan siswa dalam satu kelas

SBx :Simpangan baku skor keseluruhan siswa dalam satu kelas

$X$ :Skor yang dicapai siswa

Kecenderungan ditentukan setelah nilai (skor) tertinggi dan nilai (skor) terendah diketahui, selanjutnya nilai rata-rata ideal (Mi) dan standar deviasi ideal (Sdi). Hasil konversi nilai kuantitatif dari ahli materi, media dan siswa akan diperoleh tentang kelayakan dari pengembangan $e$ learning adaptif.

Pretes dan postes dalam rangka untuk mengetahui efektifivitas dari $e$ learning adaptif. Peningkatan hasil belajar dapat di ketahui dengan perhitungan nilai "d" (gain). Peningkatan hasil dilakukan dengan membandingkan nilai KKM sebelum digunkan (pretest) dan sesudah menggunakan (posttest) e-leanring adaptif. Rumus yang digunakan adalah sebagai berikut:

$$
\begin{array}{ll}
\hline & \mathrm{ES}=\mathrm{d}=\bar{X}_{2}-\overline{X_{1}} \\
\hline \mathrm{ES} & \text { : effect size } \\
\mathrm{d} & \text { : gain } \\
\mathrm{X} 2 & \text { : nilai rata-rata pretest } \\
\mathrm{X} 2 & \text { : nilai rata-rata posttest }
\end{array}
$$

Sebelum perhitungan nilai " $\mathrm{d}$ " data dari hasil pretest dan posttesyang berwujud angka pengukurannya dilakukan dengan penjumlahan dan pembanding, kemudian 
diambil dalam bentuk persentase sebagaimana yang diungkapkan oleh data kurangtitatif yang berwujud angka-angka hasil perhitungan atau pengukuran dapat diproses dengan caradijumlah, dibandingkan dengan jumlah yang diharapkan dan diperoleh persentase sebagimana rumus berikut ini:

\section{Kelayakan Skor yang diobservasi $(\%)=\quad$ Skor yang diharapkan $\quad$ X 100\%}

Perolehan angka tersebut dikategorikan menjadi empat bagian berdasarkan skala likert. Setelah mendapatkan jumlah persentase kelayakan maka hasilnya digolongkan kedalam skala pengukuran seperti terlihat pada Gambar 1.

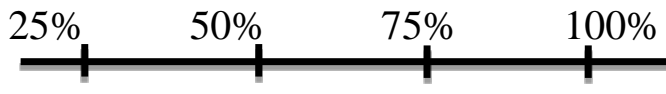

Gambar 1. Skala Pengukuran

\section{Hasil Penelitian dan Pembahasan}

Penelitian pengembangan ini menghasilkan suatu produk e-learning adaptif. Pengembangannya didasari pada konsepsi perbedaan individu yang kemudian disebut sebagai perbedaan gaya belajar. Produk ini di uji coba untuk kelas X-G SMA Negeri 11 Yogyakarta pada mata pelajaran Pendidikan Agama Islam (PAI). E-learning adaptif merupakan suatu portal media dan sumber belajar berbasis web yang dapat diakses melalui online dengan sistem akses terbuka yakni tanpa dibatasi oleh ruang dan waktu tertentu. Perbedaan e-learning yang telah banyak dikembangkan dengan e-learninga adaptif terletak dalam hal mempertimbangkan gaya belajar peserta didik, dan materi disajikan dalam 4 mode yaitu mode umum dan khusus diantaranya visual, audio, dan kinestetik. Instrumen tes gaya belajar diadopsi dari buku Duckett \& Tatarkowski (2005, p. 14), dengan jumlah soal sebanyak 18 butir. Berikut ini gambar halaman e-learning adaptif setelah dan sebelum log in

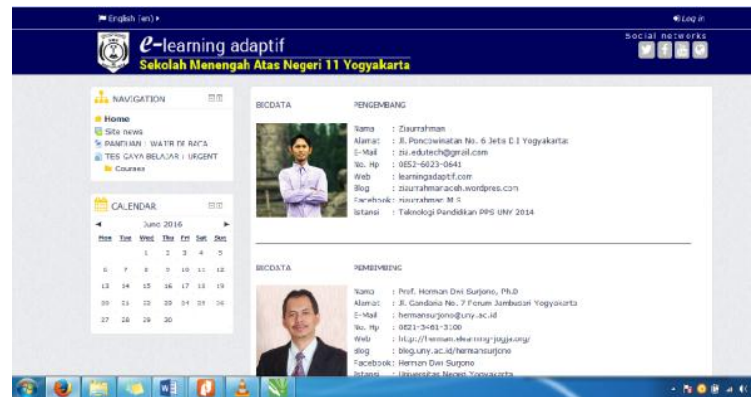

Gambar 2. Halaman sebelum dan sesudah $\log$ in

Tahapan setelah produk dikembangkan adalah memvalidasi kepada ahli media dan materi. Validasi produk dilakukan oleh 2 ahli media dan materi. Setelah validasi dan direvisi kemudian uji beta 1 kepada 5 siswa kelas X-I. Pada tahapan uji beta 1 akan dilakukan revisi setelah itu dilanjutkan dengan uji beta 2 dan evaluasi sumatif. Validasi oleh ahli materi meliputi aspek, pembelajaran, materi, leanring style, dan media. Ahli media mengevaluasi aspek, interface, navigasi, hiden fiture, accessbility, dan pengguna. Adapun penilaian yang dilakukan oleh siswa pada aspek; materi, learning style, interface, danpedagogik. Penilaian siswa terdiri dari uji beta 1 dan 2 . Selanjutnya melaksanakan tes uji sumatif untuk mengetahui perubahan dan peningkatan hasil belajar siswa dengan menggunakan e-learning adaptif sebelum dan sesudah (pretes dan postes).

Adapun hasil validasi oleh ke 2 ahli materi berdasarkan keseluruhan aspek dapat dilihat pada diagram Gambar 3.

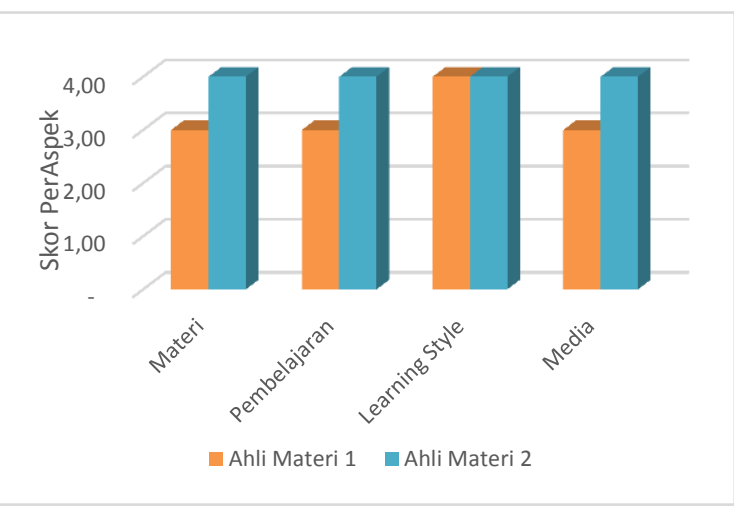

Gambar 3. Diagram Validasi Ahli Materi 
Berdasarkan gambar diagram validasi ahli materi menunjukan bahwa secara keseluruhan aspek materi yang telah dinilai oleh 2 ahli termasuk kedalam kategori sangat layak. hal tersebut terbukti berdasarkan perolehan rata-rata skor sebanyak 3,56. Adapun skor tersebut hasil dari rata-rata nilai pada aspek materi dan pembelajaran dengan jumlah skor yang sama yakni 3,50. Pada aspek learning style skor yang diperoleh sebesar 4.00 termasuk kedalam kategori sangat layak, sedangkan pada aspek media yang dinilai oleh ahli materi mendapatkan skor sebesar 3,50.

Selanjutnya hasil validasi ahli media, visualisasi skor dapat dilihat pada gambar Gambar 4.

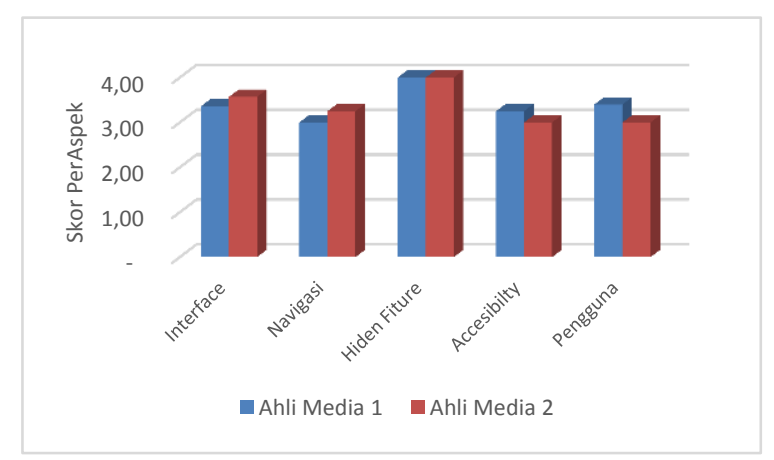

Gambar 4. Diagram Validasi Ahli Media

Gambar 4 merupakan skor hasil penilaian ke 2 ahli media dari keseluruhan aspek. Hasil validasinya termasuk kedalam kategori sangat layak, hal ini dibuktikan berdasarkan jumlah skor yang didapatkan sebesar 3,60. Adapun skor tersebut didapatkan dari hasil analisis setiap aspek yaitu, aspek Interface 3,46 termasuk kategori sangat layak, pada aspek navigasi rata-rata dari kedua ahli 3,13. Aspek Hiden Fiture 4.00, aspek Accesibilty 3,13 dan aspek pengguna didapatkan skor sebesar 3,20. Oleh karena itu pengembangan e-learning adaptif dari sisi media telah layak diimplementasi kedalam pembelajaran Pendidikan Agama Islam (PAI).

Tahapan uji selanjutnya adalah uji coba beta atau lapangan. Adapun uji coba beta dilakukan secara bertahap sebanyak 2 kali yaitu beta 1 dan 2 . Peserta didik yang ikut terlibat dalam uji beta 1 sebanyak 5 orang siswa kelas X-I SMA Negeri 11 Yogyakarta yang tediri dari 2 orang jenis gaya belajar visual 2, audio 1 , dan kinestetik 2 orang. Uji beta 1 dilakukan didalam laboratorium komputer sekolah dengan fasilitas 2 proyektor dan 60 unit perangkat komputer yang difasilitasi dengan hotspot gratis sehingga siswa dapat menghemat biaya paket internet siswa. Pada uji beta satu pengembang mengenalkan e-learning adaptif, melatih dan melakukan uji coba. Tahapan akhir pada beta satu adalah meminta siswa untuk menilaian portal e-learning adaptif yang telah di eksplorasi atau di uji coba. Adapun hasil penilaian siswa sebagaimana yang tervisualisasikan dalam Gambar 5 .

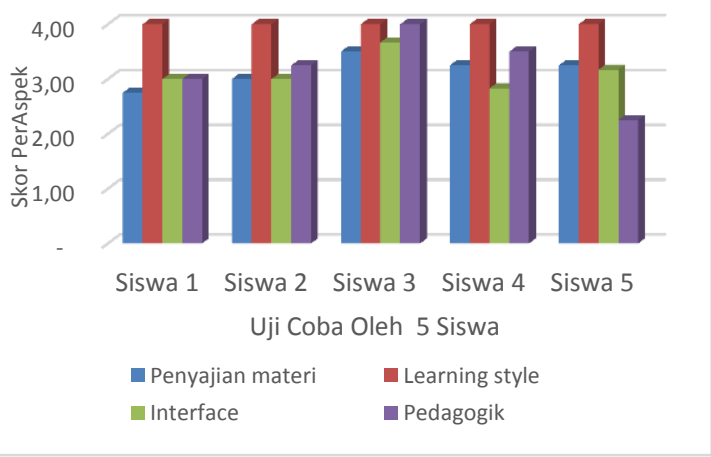

Gambar 5. Diagram Uji Beta 1

Gambar 5 menunjukan hasil keseluruhan aspek yang telah dinilai oleh siswa. Adapun jumlah skor yang diperoleh sangat variatif namun setelah rata-rata dan di konversi kedalam skla 1-4 termasuk kategori sangat layak. Nilai rata-rata keseluruhan siswa di peroleh berdasarkan penilaian masing-masing siswa pada setiap aspek. Adapun penilaian yang dilakukan oleh siswa mencakupi pada aspek penyajian materi dengan rata-rata skor 3,25, aspek learning style adalah salah satu aspek yang sangat penting dalam penerapan e-learning adaptif, adapun rata-rata skor dari 5 siswa 4.00 dengan kategori sangat layak. Aspek selanjutnya adalah interface, jadi e-leanring adaptif dikembangkan agar dapat menarik perhatian siswa, adapun jumlah skor ratarata aspek ini 3,13 termasuk ketegori sa- 
ngat layak. Aspek terakkhir dari aktivtas penilaian oleh siswa adalah pedagogik dengan jumlah skor rata-rata 3,40 termasuk kategori sangat layak.

Tahapan atau langkah selanjutnya adalah beta 2 . Adapun uji coba beta 2 dilakukan secara blended learning. Pada pertemuan awal siswa diperkenalkan dengan e-learnng adaptif dan menjelaskan tata cara penggunaan serta proses pembelajaran yang akan dijalanin selama 4 minggu pada materi pengelolaan wakaf berdasarkan undang-undang. Sebelum diajarkan dengan menggunakan e-learning adaptif siswa terlebih dahulu diberikan posttes. Adapun pembelajaran pada saat disekolah siswa belajar dengan menggunakan e-learning adaptif sebesar $30 \%$ dan $70 \%$ pembelajaran dilaksanakan secara online. Temu online siswa didampingi oleh pengembangan secara jarak jauh. Kendala-kendala yang dihadapi oleh siswa segera ditangani langsung oleh pengembang hal ini memudahkan dalam implementasi e-learninga adaptif sesuai yang telag direncakan.

Pelaksanaan pembelajaran dengan menggunakan e-learning adaptif pada jam sekolah dilaksanakan didalam laboratorium komputer sebanyak 3 kali dan 1 kali guna pengambilan dan pemberian tes sumatif (posttest) dilaksanakan didalam kelas.
Adapun jumlah siswa pada uji coba beta 2 adalah 25 yang terbagi kedalam 3 jenis gaya belajar yaitu visual yang berjumlah 6 orang, audio sebanyak 2 orang, dan kinestetik merupakan tipe terbanyak didalam kelas X-G yatitu sebanyak 17 orang siswa. Kelas uji coba beta 2 adalah kelas X-G SMA Negeri 11 Yogyakarta.

Adapun rincian hasil penilaian oleh siswa pada uji beta 2 dijabarkan dalam dua tahapan. Tahap pertama analisis rincian data rata-rata dari setiap aspek berdasarkan perorangan. Tujuan uji beta 2 adalah untuk mengetahui kelayakan produk.

Diagram beta 2 merupakan hasil analisis data tentang aspek yang mengukur tingkat kelayakan produk. Adapun siswa yang terlibat pada saat uji beta 2 sebanyak 25 orang kelas X-G SMA Negeri 11 Yogyakarta yang terdiri dari berbagai tipe gaya belajar. Jumlah siswa dengan gaya belajar visual 6 orang, audio 2 orang, dan kinestetik 17. Gaya belajar yang mendominasi adalah kinestetik. Hasil konversi data baik dianalisis berdasarkan gaya belajar atau keseluruhan rata-rata nilainya termasuk kategori sangat layak dengan jumlah skor sebesar 3,39. Adapun data rata-rata skor dari masing-masing aspek dapat diketahui melalui Tabel 3.

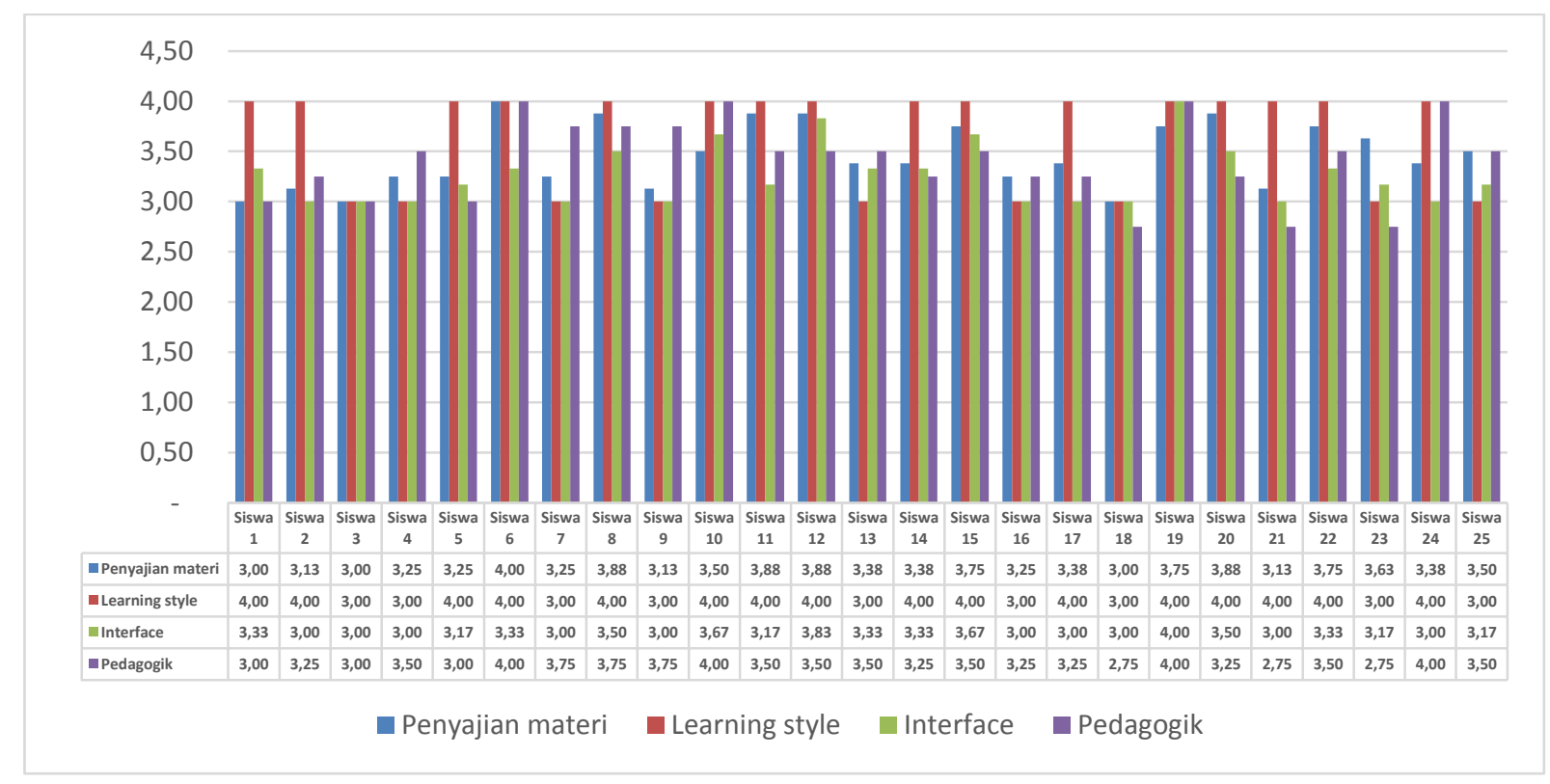

Gambar 6. Diagram Uji Beta 2 
Tabel 3. Nilai Rerata Aspek

\begin{tabular}{lc}
\hline \multicolumn{1}{c}{ Aspek } & Rerata 25 Siswa \\
\hline Penyajian materi & 3,45 \\
Learning style & 3,64 \\
Interface & 3,26 \\
Pedagogik & 3,41 \\
\hline
\end{tabular}

Tabel 3 tentang nilai rerata skor dari setiap aspek. Rerata skor setiap dinyatakan sangat layak setelah dikonversi ke dalam skala liker 1-4. Aspek penyajian materi skor yang diperoleh 3,45. Aspek learning style adalah aspek yang sangat penting dan menjadi penilain khusus karena berkaitan dengan landasan pengembangan $e$ learning adaptif salah satunya didasari atas adanya perbedaan gaya belajar, adapun skor yang didapatkan termasuk kategori sangat layak 3,64. Aspek interface nilainya 3,26 termasuk kategori sangat layak, dan pedagogik aspek terkahir dari uji beta 2 dengan perolehan rerata skor 3,41.

Berdasrkan penjabaran nilai uji beta 1 oleh 5 siswa dan pada uji beta 2 dengan jumlah siswa 25 orang memperjelaskan tentang kedudukan dan keyalayakan produk e-learning adaptif sangat layak digunakan dalam pembelajaran Pendidikan Agama Islam (PAI) pada materi pengelolaan wakaf berdasarkan undang-undang.

Setelah mengetahui kelayakan produk melalui uji coba beta 1 dan 2 kemudian dilaksanakan tes sumatif. Tes sumatif bertujuan untuk mengetahui peningkatan hasil belajar siswa yang dilaksanakan satu minggu setelah pembelajaran. Tes sumatif ini diberikan kepada kepada siswa kelas XG SMA Negeri 11 Yogyakarta melalui tahapan pretes dan postes. Perolehan data pretes dan postes dianalisis kemudian membandingkan untuk mengetahui berapa tinggi atau terjadinya signifikan hasil belajar antara pretes dan postes. Artinya tahapan pretes dan postes adalah untuk mencari nilai "gain", berikut ini dapat dilihat hasil prestes dan postes pada tabel 4.
Tabel 4. Perbandingan Data Uji

Kompetensi KognitifPretest dan Posttest

\begin{tabular}{llll}
\hline No & Variabel & Pretest & Posttest \\
\hline $1 \quad$ Nilai Terendah & 30 & 75 \\
$2 \quad$ Nilai Tertinggi & 80 & 95 \\
Jumlah & 110 & 170 \\
Rata-rata & 55 & 85 \\
Gain Skor & 140 & \\
\hline
\end{tabular}

Tabel 4 merupakan skor yang dihasilkan melalui analisis data terhadap nilai pretes dan postes. Hasilnya menunjukan terjadinya peningkatan hasil antara sebelum dan sesudah menggunakan e-learning adaptif. Oleh karena itu indikator dan tujuan materi pengelolaan wakaf berdasarkan undang-undang pada mata pelajaran Pendidikan Agama Islam (PAI) sudah tercapai sebagaimana harapan dari pengembangan e-learning adaptif adalah sebagai salah satu solusi dari permasalahan yang ada di SMA Negeri 11 Yogyakarta. Ketercapain indikator atau tujuan pembelajaran didasari pada ketetapan nilai KKM yaitu 75, dan semua siswa sudah mencapainya.

Analisi data selanjutnya adalah untuk mengetahui peningkatan hasil belajar berdasarkan kelompok gaya belajar. Penelitian pengembangan ini mengakomodasi satu tipe gaya belajar artinya tidak melihat pengaruh pada jenis gaya belajar campuran. Adapun gaya belajar yang dimaksud adalah visual, audio, dan kinestetik. Data rata-rata masing-masing kelompk gaya belajar sebagaimana tervisualisasi pada Tabel 5.

Tabel 5. Perbadingan Rata-Rata Skor Pretest dan Posttest berdasrkan Kelompok Gaya Belajar

\begin{tabular}{clc|c}
\hline Gaya & Pretestt & posttest & Gain \\
\cline { 2 - 3 } Belajar & Score & Score & Score \\
\hline Visual & 48,33 & 83,33 & 35 \\
Audio & 52,5 & 57,5 & 5 \\
Kinestetik & 48,23 & 82,35 & 34,12 \\
Rata-rata & 149,06 & 223,18 & 74,2 \\
\hline
\end{tabular}


Berdasarkan data yang tercantum pada tabel 5 tentang hasil pembelajaran berdasarkan kelompok gaya belajar. Maka pembelajaran berdasarkan kelompok gaya belajar menunjukan terjadinya perubahan dan peningkatakan hasil, baik dari gaya belajar visual, audio, dan kinestetik. Ratarata peningkatan hasil belajar tergolong tinggi, hal ini didasari pada jumlah kelompok belajar. Namun jumlah skornya tidak sama, karena sebaran data tidak merata artinya ada yang tinggi, sedang, dan renda pada tipe gaya belajar tertentu. Misalnya dalam penelitian ini yang paling tinggi adalah kinestetik dengan jumlah siswa 17 orang maka gain skornya juga tinggi. Nilai gain skor ini di bandingkan antara pretes dan postes. Oleh sebab itu pengembangan e-learning adaptif dikatakan dapat memberikan manfaat dan efektif karena muncul peningkatan hasil belajar baik secara global maupun berdasarkan gaya belajar.

E-learning adapati yang dikembangkan memiliki beberapa keunggulan (1) desaian pesan intruksional dilakukan berdasarkan hasil analisis kebutuhan, (2) materi disajikan berbagai macam ragam visual, audio, dan kinestetik, (3) dapat diakses dengan menggunakan handphone, PC, dan laptop dimana saja dan kapan saja tanpa dibatasi oleah ruang dan waktu tertentu, (3) e-leaning adaptif difasilitasi tes gaya belajar, (4) dikembangkan berdasarkan gaya belar behavioristik, kognitif, dan konstruktivistik sehingga segala informasi dan kemudahan dapat diterima oleh pengguna, (5) dapat diintegrasikan terhadap mata pelajaran yang lain karena konsep awal sudah difasilitasi yaitu tes gaya belajar, (6) termasuk kedalam kategori sangat layak baik dari segi produk maupun peningkatan hasil belajar, dan (7) memiliki interaktifitas yang dapat menarik peminat peserta didik.

Adapun kelemahan dari e-learning adaptif pada penelitian pengembangan ini adalah sistem akses bersifat tertutup, artinya peserta didik dengan tipe gaya belajar tertentu misalnya visual, audio, ataupun kinestetik tidak dapat saling memberikan askses untuk mempelajari materi. selain itu masih terbatas pada satu mata pelajaran, dan lembaga sekolah. Sementara keterbatasan selanjutnya bahwa e-learning adaptif sebelum digunakan perangkat laptop, PC, ataupun Handphone harus benar-benar sudah aktif flash player hal ini berfungsi pada saat mengakses mataeri pada jenis gaya belajar visual, dan kinestetik.

\section{Simpulan}

Berdasarkan hasil penelitian dan pengembangan e-learning adaptif dapat disimpulkan sebagai berikut; Hasil Penelitian pengembangan e-learning adaptif dikembangkan atas dasar adanya peningkatan hasil belajar berdasarkan gaya belajar $\mathrm{p}$ eserta didik. Pengembangan e-learning adaptif berbasis web diterapkan pada SMA Negeri 11 Yogyakarta kelas X-G semester genap tahun Ajaran 2015/2016 pada materi pengelolaan wakaf berdasarkan undangundang. Adapun hasil produk dapat dilihat melalui situs learning adaptif.com.

Produk e-learning adaptif dinilai atau divalidasi oleh 2 ahli materi dan media (uji alpha). Tahapan penilaian lanjutan adalah uji coba beta satu sebanyak 5 orang dan 25 orang pada beta dua dengan multi gaya belajar (uji coba beta). Model gaya belajar yang diadopsi adalah visual, audio, dan kinestetik (VAK). Hasil validasi oleh ahli dan uji coba pada siswa maka $e$ learning adaptif sebagai sumber dan media belajar dinyatakan layak danadanya peningkatan hasil belajar.

Kelayakan produk e-learning adaptif berbasis web berdasarkan uji alpha dan beta: (a) hasil uji coba alpha oleh ahli materi 1 diperoleh nilai rata-rata sebesar 3,12 dengan kategori sangat layak. Sedangkan ahli materi 2 nilai rata-ratanya 4,00 dengan kategori sangat layak; (b) hasil uji coba alpha oleh ahli media 1 diperoleh nilai rata-rata sebesar 3,34 dengan kategori sangat layak. Sedangkan ahli media 2 nilai rata-ratanya 3,38 dengan kategori sangat layak. (c) Hasil penilaian atau uji beta satu diper-oleh nilai rata-rata sebesar 3,24 
dengan kategori sangat layak. Sedangkan pada uji coba beta dua nilai rata-rata yang didapatkan 3,39 dengan kategori sangat layak.

Kebermanfaatan produk meruju pada hasil tes sumatif yang dilakukan terhadap 25 siswa kelas X-G SMA Negeri 11 Yogyakarta.Adapun hasil evaluasi sumatif diperoleh nilai rata-rata pada saat pretest sebesar 48,60 dan posttest 82.60. Peningkatan nilai hasil belajar sebesar $34 \%$. dengan jumlah persentase ketuntasan KKM adalah $100 \%$. Oleh sebab itu, penerapan e-learning adaptif pada mata pelajaran PAI materi wakaf di SMA Negeri 11 Yogyakarta kelas X-G dinyatakan efektif.

Berdasarkan hasil penelitian dan simpulan yang disajikan maka dapat disampaikan saran sebagai berikut. Dalam pemanfaatan produk e-learning adapatif terdapat beberapa hal yang perlu dipersiapkan oleh guru yaitu mengindentifikasi materi, mengembangkan isi materi dalam bentuk multimedia, guru perlu membudayakan pembelajarana berbasis online, dan upayakan semangat dalam melahirkan inovasi terhadap penyajian materi berdasarkan kebutuhan peserta didik. E-learning adaptif agar dapat dimanfaatkan tidak hanya pada mata pelajaran Pendidikan Agama Islam namun juga untuk mata pelajaran yang lain dan lembaga-lembaga sekolah baik formal maupun non formal. Melalui pemanfaatan e-learning adaptif guru tidak perlu khawatir terkait alokasi waktu yang minim dialokasikan, karena e-learning adaptif dapat dilaksanakan secara online.

\section{Daftar Pustaka}

Alessi, S. M. \& Trollip, S. R. (2001). Multimedia for learning: methods anddevelopment (third edition). Boston:Allyn and Bacon.

Ally, M. (2004). Foundations of educational theory for online learning. In $T$. Anderson \& F. Elloumi (Eds.), Theory and practice of online learning (pp.3-31): Athabasca University and lessons learned. San fransisco: Pfeiffer.
Badan Standar Nasional Pendidikan.(2010). Paradigma pendidikan nasional abad XXI. Jakarta

Badan Standar Nasional Pendidikan. (2006) Standar kompetensi dan kompetensi dasar $S M A / M A$ : Jakarta

Bersin, J. (2004). The blended learning book. Best practices, proven methodologies. Sanfrancisco: Pfeiffe.

Brusilovsky, P. (2001). Adaptive hypermedia. Kluwer Academic Publishers. Printed in the Netherlands, $11,87-110$

Duckett, I \& Tatarkowski, M. (2005). Practical strategies For learning and teaching on vocational programmes. London: Learning and skills development agency.

Engku, I \& Zubaidah, S. (2014). Sejarah pendidikan islam. Bandung: Remaja Rosadakarya:

Greenstein, L. M. (2012). Assessing 21st century skills: A guide to evaluating mastery and authentic learning. London: Corwin.

Henderson, A. J. (2003). The e-learning question and answer book: A survival guide for trainers and business managers. New York: Amacom.

Horton, W \& Horton, K. (2003).E-learning tools and technologies: A consumer's guide for trainers, teachers, educators, and instructional designers. Canada: Wiley Publishing, Inc.

Kementrian Agama Rebulik Indonesia. (2015). Malik fadjar sedih guru agama keluhkan jam mengajar. Retrieved from http://www.kemenag.go.id/index.ph p?a $=$ berita\&id $=279876$

Badan Penelitian dan Pengembangan Kementerian Pendidikan dan Kebudayaan. (2013). Kurikulum 2013: pergeseran paradigma belajar abad21. Retrieved September 29, 2015, from http://litbang.kemdikbud.go.id/inde 
x.php/index-berita-kurikulum/243 kurikulum-2013-pergeseranparadigma-belajar-abad-21

Magdalena, S.M. (2014). The relationship of learning styles, learning behaviour and learning outcomes at the romanian students. Procedia - Social and Behavioral Sciences 180, 1667 - 1672. doi:10.1016/j.sbspro.2015.05.062

Mardapi, D. (2008). Teknik penyusunan instrument tes dan nontes. Yogyakarta: Mitra Cendikia Press:

Naidu, S. (2006). E-learning a guidebook of pronciples, prosedures and practices 2 nd revised edition. New Delhi:

Commonwealth Educational MediaCenter for Asia.

Pannen, P. (Desember 2005). Pengembangan e-learning: antara mitos dan kenyataan. In Seminar Nasional Teknologi Pembelajaran. Universitas Neger Jakarta

Permadi, A.(2015). Pengembangan bahan ajar berbasis web berdasarkan gaya belajar siswa untuk mata pelajaran fisika pada siswa kelas $x$ sma negeri 1 sukamulia kabupaten lombok timur. S2 thesis, UNY.

Pheeraphan, N. (2013). Enhancement of the 21st century skills for thai higher education by integration of ict in classroom. Procedia - Social and Behavioral Sciences, 103, 365-372

Rusman, K. D, \& Riayana, C. (2012). Pembelajaran berbasis teknologi dan komunikasi. Jakarta: Rajawali Pers.

Surjono, H. D. (2008). Pengembangan model e-learning adaptif terhadap keragaman gaya belajar mahasiswa untuk meningkatkan efektivitas pembelajaran. Yogyakarta: UNY.

Surjono, H. D. (2011). The design of adaptive e-learning system based on student's learning styles. Internasional Journal of Computer Science Information and Education Technology (IJSCIT), 2(5), 2350-2353

Surjono, H. D. (2013). Membangun course elearning berbasis moodle. (2nd ed.). Yogyakarta: UNY Press. 